\title{
PELATIHAN PENYUSUNAN LAPORAN HASIL PENELITIAN TINDAKAN KELAS UNTUK GURU SD NEGERI 5 PADANGSAMBIAN
}

N L P Agetania1), N L P Mery Marlinda1), I M Dedy Setiawan1), I K A Diansih Fortuna'), Emmy Febriani Thalib ${ }^{1)}$, I P Hendika Permana ${ }^{1)}$, I P G Eka Suryana ${ }^{1)}$, N N Widiyaningsih ${ }^{1)}$, K Laksmi Maswari')

1)Teknik Informatika, STMIK STIKOM Indonesia, Denpasar, Bali, Indonesia

Corresponding author : N L P Agetania

E-mail : niluhputuagetania@gmail.com

Diterima 05 Mei 2020, Direvisi 04 Juni 2020, Disetujui 04 Juni 2020

\begin{abstract}
ABSTRAK
Dalam kegiatan pembelajaran, seorang guru sudah pasti akan berhadapan dengan berbagai persoalan baik menyangkut peserta didik, subject matter, maupun metode pembelajaran. Sebagai seorang profesional, guru harus melakukan peningkatan mutu pembelajaran secara terus menerus agar prestasi belajar peserta didik optimal. Untuk mewujudkan hal tersebut guru harus dibekali dengan kemampuan meneliti, khususnya Penelitian Tindakan Kelas. Tujuan dari kegiatan pengabdian ini adalah meningkatkan kemampuan guru-guru SD Negeri 5 Padangsambian, dalam menyusun laporan PTK yang sesuai dengan sistematika. Pelaksanaan kegiatan pengabdian masyarakat meliputi beberapa kegiatan yaitu Pengumpulan Data, Indentifikasi Masalah, Analisis Kebutuhan Materi Pelatihan, Perancangan dan Penyusunan Modul Pelatihan, Pelaksanaan Pelatihan, dan Dokumentasi Kegiatan dan Laporan. Dari kegiatan pengabdian masyarakat yang dilakukan, dapat ditarik kesimpulan bahwa pelatihan penyusunan laporan PTK kepada guru-guru SD Negeri 5 Padangsambian yang telah dilakukan, mampu meningkatkan kemampuan guru-guru dalam penyusunan laporan PTK sebesar $81,26 \%$.
\end{abstract}

Kata kunci: pelatihan; penelitian tindakan kelas.

\begin{abstract}
In learning activities, a teacher will certainly be dealing with various problems both regarding students, subject matter, and learning methods. As a professional, teachers must continuously improve the quality of learning so that students' learning achievement is optimal. To realize this the teacher must be equipped with the ability to research, especially Classroom Action Research. The purpose of this community service activity is to improve the ability of Padangsambian 5 Elementary School teachers to compile PTK reports in accordance with systematics. The implementation of community service activities includes several activities, namely Data Collection, Problem Identification, Analysis of Training Material Requirements, Training Module Design and Preparation, Training Implementation, and Documentation of Activities and Reports. From the community service activities carried out, it can be concluded that the PTK report preparation training for Padangsambian State Elementary School 5 teachers has been able to improve the ability of teachers in PTK report preparation by $81.26 \%$
\end{abstract}

Keywords: training; classroom action research

\section{PENDAHULUAN}

Undang-undang RI Nomor 14 Tahun 2005 tentang Guru dan Dosen, merupakan bukti pengakuan terhadap profesionalitas pekerjaan guru dan dosen semakin mantap. Terlebih lagi di dalam pasal 14 dan 15 Undangundang tersebut dinyatakan bahwa guru berhak memperoleh penghasilan di atas kebutuhan hidup minimum dan jaminan kesejahteraan sosial, meliputi gaji pokok, tunjangan yang melekat pada gaji, serta penghasilan lain berupa tunjangan profesi, tunjangan fungsional, tunjangan khusus, dan maslahat tambahan yang terkait dengan tugasnya sebagai guru yang ditetapkan dengan prinsip penghargaan atas dasar prestasi.

Bagi para guru pengakuan dan penghargaan di atas harus dijawab dengan meningkatkan profesionalisme dalam bekerja. Sehingga guru harus menunjukkan komitmen dan tanggung jawab yang tinggi. Setiap kinerjanya harus dapat dipertanggung jawabkan baik secara publik maupun akademik. Untuk itu ia harus memiliki landasan teoretik atau keilmuan yang mapan dalam melaksanakan tugasnya mengajar maupun membimbing peserta didik. Dalam kegiatan pembelajaran, seorang guru sudah pasti akan 
berhadapan dengan berbagai persoalan baik menyangkut peserta didik, subject matter, maupun metode pembelajaran. Sebagai seorang profesional, guru harus melakukan peningkatan mutu pembelajaran secara terus menerus agar prestasi belajar peserta didik optimal. Untuk mewujudkan hal tersebut guru harus dibekali dengan kemampuan meneliti, khususnya Penelitian Tindakan Kelas.

Dengan adanya sertifikasi guru saat ini, para pendidik dituntut untuk mampu meneliti. Tuntutan agar guru mampu meneliti semakin gencar dilakukan oleh pemerintah. Hal itu dibuktikan dari laporan portofolio guru yang mensyaratkan melampirkan karya tulisnya dalam sertifikasi guru dalam jabatan karena hal itulah maka guru-guru di sekolah harus dapat meneliti di kelasnya sendiri dengan tujuan memperbaiki kualitas pembelajarannya melalui Penelitian Tindakan Kelas (PTK). PTK sesungguhnya merupakan implementasi dari kreativitas dan kekritisan seorang guru terhadap apa yang sehari-hari diamati dan dialaminya sehubungan dengan profesinya untuk menghasilkan kualitas pembelajaran yang lebih baik sehingga mencapai hasil belajar yang optimal. SD Negeri 5 Padangsambian adalah sebuah sekolah dasar yang berlokasi di Kecamatan Denpasar Barat Provinsi Bali. Gambar 1 memperlihatkan SD Negeri 5 Padangsambian yang menjadi lokasi diadakannya kegiatan pengabdian kepada masyarakat (PKM) ini.

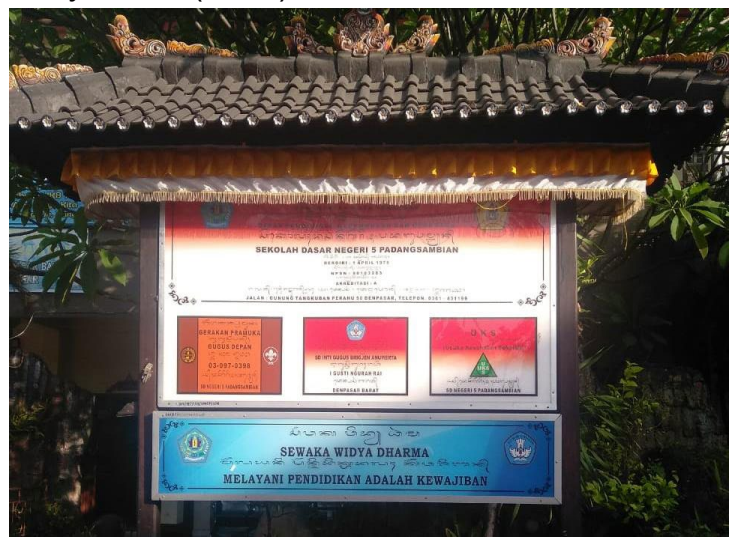

Gambar 1. Sekolah Dasar Negeri 5 Padangsambian

Berdasarkan hasil wawancara dan observasi yang dilakukan dengan beberapa guru SD Negeri 5 Padangsambian di Denpasar Barat, diketahui bahwa kemampuan guru-guru SD Negeri 5 Padangsambian dalam menyusun laporan PTK masih belum maksimal. Hal ini dapat dilihat dari bentuk laporan PTK yang mereka hasilkan sebelumnya.

Berdasarkan hal tersebut dipandang perlu untuk memberikan pelatihan penyusunan laporan PTK bagi Guru - Guru SD Negeri 5 Padangsambian Kecamatan Denpasar Barat. Sehingga dengan pelaksanaan pelatihan ini diharapkan guru - guru mampu menyusun laporan PTK lebih baik lagi.

Berdasarkan hasil wawancara awal dengan kepala sekolah SD Negeri 5 Padangsambian, sebagian besar guru kurang mampu menyusun laporan hasil PTK sehingga mereka membutuhkan waktu yang cukup lama dalam penyusunan laporan PTK akibat pemahaman yang kurang lengkap dan jelas. Sehingga berdasarkan latar belakang di atas, dapat dirumuskan permasalahan yaitu sebagian besar guru - guru di SD Negeri 5 Padangsambian kurang memiliki kemampuan dalam penyusunan laporan PTK. Berdasarkan permasalahan yang telah diuraikan sebelumnya, maka dapat diajukan solusi yang diharapkan nantinya dapat meningkatkan kemampuan dalam menyusun laporan PTK.

Solusi yang dapat ditawarkan untuk menangani permasalahan yang dialami oleh SD Negeri 5 Padangsambian Denpasar Barat adalah kegiatan dengan materi penyusunan laporan PTK. Manfaat yang diperoleh guru-guru SD dari pelaksanaan kegiatan pokok diatas adalah Guru-guru SD Negeri 5 Padangsambian Denpasar Barat mampu menyusun PTK serta membuat laporan PTK dengan sistematika yang baku. Sehingga solusi kegiatan pengabdian masyarakat ini diharapkan mampu menjadi solusi atas kendala yang dihadapi guru-guru di SD Negeri 5 Padangsambian Kecamatan Denpasar Barat, khususnya terkait dengan penyusunan laporan PTK yang sesuai dengan sistematika. Tujuan dari kegiatan pengabdian ini adalah meningkatkan kemampuan guru-guru SD Negeri 5 Padangsambian, dalam menyusun laporan PTK yang sesuai dengan sistematika.

\section{METODE}

Pelaksanaan kegiatan pengabdian masyarakat meliputi beberapa kegiatan yaitu Pengumpulan Data, Indentifikasi Masalah, Analisis Kebutuhan Materi Pelatihan, Perancangan dan Penyusunan Modul Pelatihan, Pelaksanaan Pelatihan, dan Dokumentasi Kegiatan dan Laporan. Alur pelaksanaan kegiatan pengabdian masyarakat disajikan pada gambar 2 . 


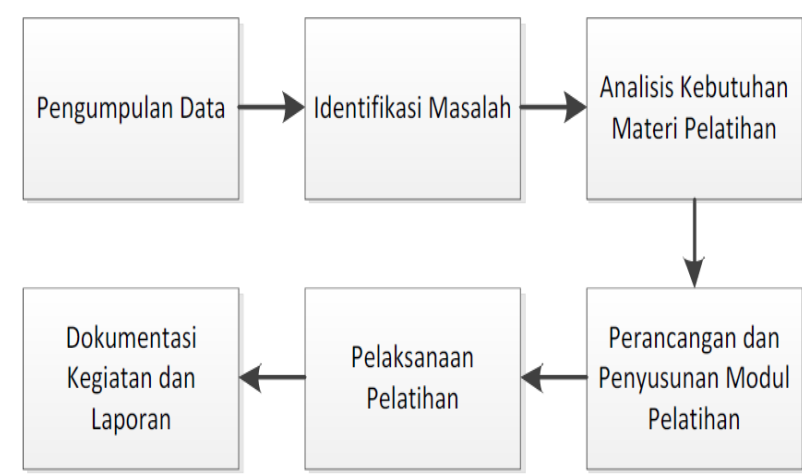

Gambar 2. Alur Pelaksanaan Kegiatan pengabdian masyarakat

Alur pelaksanaan kegiatan pengabdian masyarakat diatas akan dijelaskan secara lebih terperinci pada subbab dibawah ini.

\section{Pengumpulan Data}

Tahapan pertama dalam kegiatan pengabdian masyarakat ini adalah pengumpulan data. Kegiatan ini bertujuan untuk mengetahui kondisi di SD Negeri 5 Padangsambian Denpasar Barat. Berdasarkan hasil wawancara dan observasi yang dilakukan dengan beberapa guru SD Negeri 5 Padangsambian Denpasar Barat, diketahui bahwa kemampuan menyusun laporan PTK sebagian guru masih kurang maksimal. Hal ini dapat dilihat dari sedikitnya guru-guru yang mampu membuat laporan PTK sesuai dengan sistematika penulisannya.

\section{Identifikasi Masalah}

Setelah dilakukan pengumpulan data selanjutnya dilaksanakan identifikasi masalah. Identifikasi masalah dilakukan untuk mengetahui masalah yang dihadapi oleh SD Negeri 5 Padangsambian Denpasar Barat dalam penyusunan laporan PTK oleh para guru.

\section{Analisis Kebutuhan Materi Pelatihan}

Berdasarkan identifikasi masalah yang dilakukan, maka materi yang dibutuhkan oleh guru-guru di SD Negeri 5 Padangsambian Denpasar Barat berkaitan dengan alur PTK, serta sistematika penyusunan laporan PTK.

Pelatihan materi tersebut bertujuan untuk memberikan pengetahuan kepada guru tentang alur PTK dan sistematika penyusunan laporan PTK.

\section{Perancangan dan Penyusunan Modul Pelatihan}

Untuk mempermudah dalam kegiatan pelatihan maka perlu disusun modul pelatihan. Modul ini nantinya akan dijadikan sebagai panduan oleh para guru ketika pelatihan sedang berlangsung, ataupun dapat digunakan sebagai bahan belajar secara mandiri ketika kegiatan pengabdian masyarakat telah selesai. Untuk itu maka modul akan disusun secara baik sehingga mudah dipahami dan dapat digunakan untuk belajar secara mandiri oleh para guru. Setiap guru yang menjadi peserta pelatihan akan diberikan sebuah modul yang telah dicetak.

\section{Pelaksanaan Pelatihan}

Pelaksanaan pelatihan akan dilaksanakan di SD Negeri 5 Padangsambian Denpasar Barat dalam masa waktu kegiatan pengabdian masyarakat ini. Kegiatan akan dilakukan selama 4 hari dengan lama pelatihan 8 jam sehari. Kegiatan akan diikuti oleh 30 guru.

\section{Dokumentasi Kegiatan dan Laporan}

Dokumentasi kegiatan akan dilakukan dalam bentuk foto kegiatan dan laporan kegiatan. Dokumentasi kegiatan merupakan salah satu bukti dari pelaksanaan kegiatan yang telah dilakukan. Disamping itu juga, dokumentasi kegiatan berupa laporan dapat dijadikan sebagai evaluasi terhadap kegiatan pengabdian masyarakat yang telah dilaksanakan. Hal ini juga akan menjadi pedoman dalam kegiatan pengabdian masyarakat sejenis yang akan dilaksanakan di kemudian hari.

\section{HASIL DAN PEMBAHASAN}

Berdasarkan hasil wawancara awal dengan kepala sekolah SD Negeri 5 Padangsambian, sebagian besar guru kurang mampu menyusun laporan hasil PTK sehingga mereka membutuhkan waktu yang cukup lama dalam penyusunan laporan PTK akibat pemahaman yang kurang lengkap dan jelas. Sehingga berdasarkan latar belakang di atas, dapat dirumuskan permasalahan yaitu sebagian besar guru - guru di SD Negeri 5 Padangsambian kurang memiliki kemampuan dalam penyusunan laporan PTK.

Berdasarkan permasalahan yang telah diuraikan sebelumnya, maka dapat diajukan solusi yang diharapkan nantinya dapat meningkatkan kemampuan dalam menyusun laporan PTK.

Solusi yang dapat ditawarkan untuk menangani permasalahan yang dialami oleh SD Negeri 5 Padangsambian Denpasar Barat adalah kegiatan dengan materi penyusunan laporan PTK. Manfaat yang diperoleh guru-guru SD dari pelaksanaan kegiatan pokok diatas adalah Guru-guru SD Negeri 5 Padangsambian Denpasar Barat mampu menyusun PTK serta membuat laporan PTK dengan sistematika yang baku. Sehingga solusi kegiatan pengabdian masyarakat ini diharapkan mampu menjadi solusi atas kendala yang dihadapi 
guru-guru di SD Negeri 5 Padangsambian Kecamatan Denpasar Barat, khususnya terkait dengan penyusunan laporan PTK yang sesuai dengan sistematika. Tujuan dari kegiatan pengabdian ini adalah meningkatkan kemampuan guru-guru SD Negeri 5 Padangsambian, dalam menyusun laporan PTK yang sesuai dengan sistematika.

Berdasarkan rencana kegiatan yang telah disusun maka target luaran yang diharapkan setelah Kegiatan Pengabdian Masyarakat adalah ditunjukan pada tabel 1.

Tabel 1. Daftar Kegiatan Pengabdian Masyarakat dan Target Luaran pada Mitra

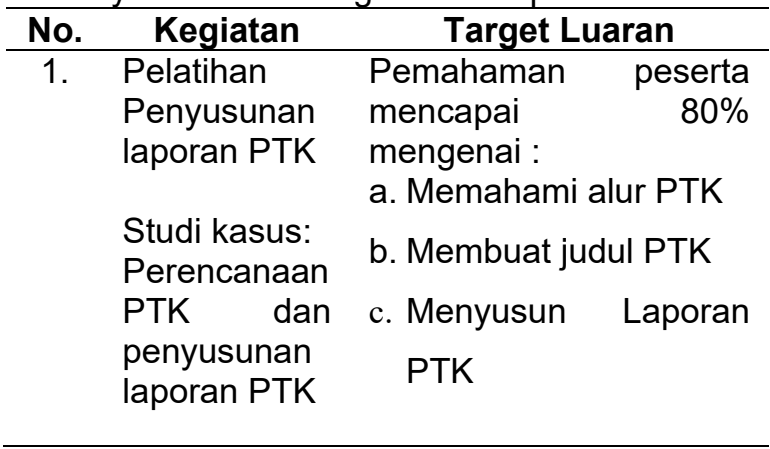

\section{Pelaksanaan Kegiatan PKM}

Kegiatan PKM di SD Negeri 5 Padangsambian Denpasar Barat, dilaksanakan pada hari Selasa-Kamis, 14-17 Maret 2019. Kegiatan PKM dilakukan terhadap guru-guru di SD Negeri 5 Padangsambian Denpasar Barat dengan memberikan pelatihan penyusunan laporan PTK. Kegiatan PKM yang dilakukan mendapat dukungan dari Kepala Sekolah SD Negeri 5 Padangsambian Denpasar Barat. Hal ini dapat dilihat dari antusias beliau membuka pada awal pelaksanaan kegiatan PKM sekaligus ikut dalam kegiatan PKM selama 3 hari.

Kegiatan pelatihan berlangsung selama 4 hari yaitu pada hari Selasa-Kamis, 14-17 Maret 2019, bertempat di ruang aula SD Negeri 5 Padangsambian Denpasar Barat. Kegiatan diikuti oleh 30 orang guru. Materi pelatihan yang diberikan adalah penyusunan laporan PTK.

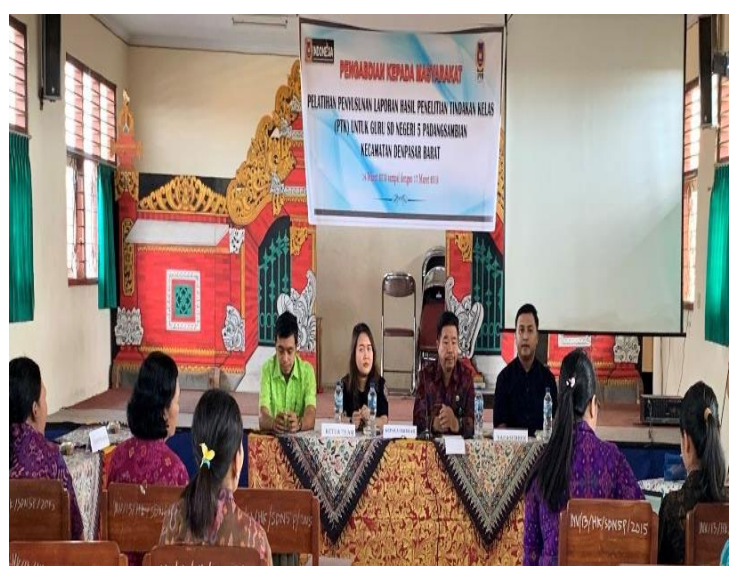

Gambar 3. Sambutan Kepala Sekolah

Gambar 3 merupakan dokumentasi ketika Kepala Sekolah memberikan sambutan saat awal kegiatan PKM yang dihadiri oleh guru-guru SD Negeri 5 Padangsambian Denpasar Barat. Kepala Sekolah sangat mendukung diadakannya kegiatan PKM, mengingat manfaat penelitian ini bagi para guru dan demi perbaikan pembelajaran di kelas. Akhir sambutan Kepala Sekolah menyampaikan ucapan terima kasih atas terpilihnya SD Negeri 5 Padangsambian sebagai lokasi pelaksanaan kegiatan PKM. Harapannya, materi pelatihan yang diberikan dapat dipahami dan diterapkan oleh perserta pelatihan yang dalam hal ini adalah guru-guru SD Negeri 5 Padangsambian.

Kegiatan pelatihan berlangsung selama 4 hari yaitu pada hari Kamis-Minggu, 14-17 Maret 2019, bertempat di ruang aula SD Negeri 5 Padangsambian. Kegiatan diikuti oleh 30 orang guru. Materi pelatihan yang diberikan adalah pelatihan penyusunan laporan hasil penelitian tindakan kelas (PTK).

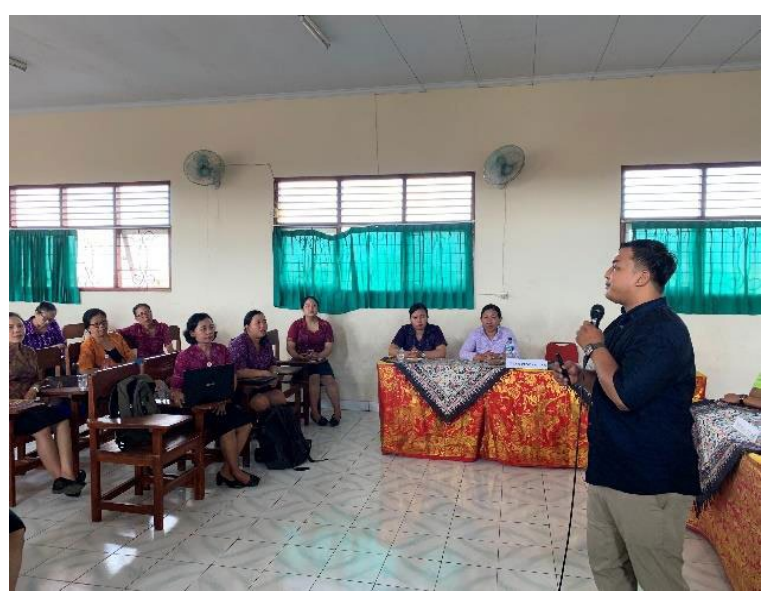

Gambar 4. Guru-guru SD mengikuti pelatihan penyusunan laporan PTK 


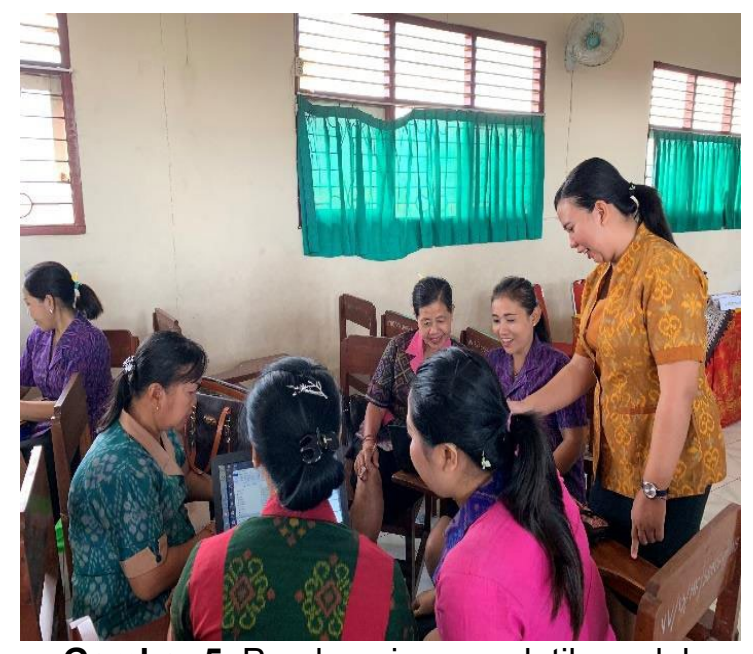

Gambar 5. Pendampingan pelatihan oleh

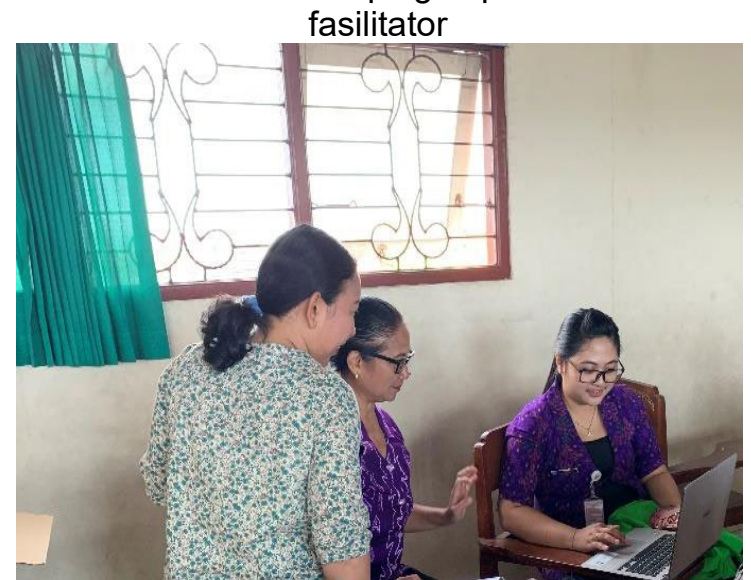

Gambar 6. Fasilitator membantu peserta yang kesulitan mengikuti pelatihan

Gambar 4, Gambar 5, dan Gambar 6 merupakan dokumentasi selama kegiatan pelatihan berlangsung. Peserta tidak hanya dipandu oleh dua orang mentor, namun juga diberikan pendampingan oleh fasilitator. Hal ini dilakukan agar peserta dapat mengikuti pelatihan secara menyeluruh dan tidak sampai ketinggalan. Selain itu, fasilitator memberikan semangat bagi peserta dalam mengikuti pelatihan, karena fasilator selalu membantu ketika peserta menghadapi kendala, sehingga permasalahan yang dialami dapat segera diselesaikan.

Peserta sangat antusias mengikuti pelatihan. Hal ini ditunjukkan oleh kehadiran peserta yang selalu tepat waktu dan mengikuti pelatihan sampai selesai. Setiap kendala yang dihadapi peserta selalu aktif bertanya. Setelah kegiatan tanya jawab selesai dan peserta dirasa sudah memahami materi yang diberikan maka akan dilaksanakan post-test untuk melihat seberapa jauh pemahaman dan peningkatan dari materi yang disampaikan. Sebelum post test dilakukan maka diadakan sesi foto Bersama antara peserta pelatihan dan mentor seperti terlihat pada gambar 7 di bawah.

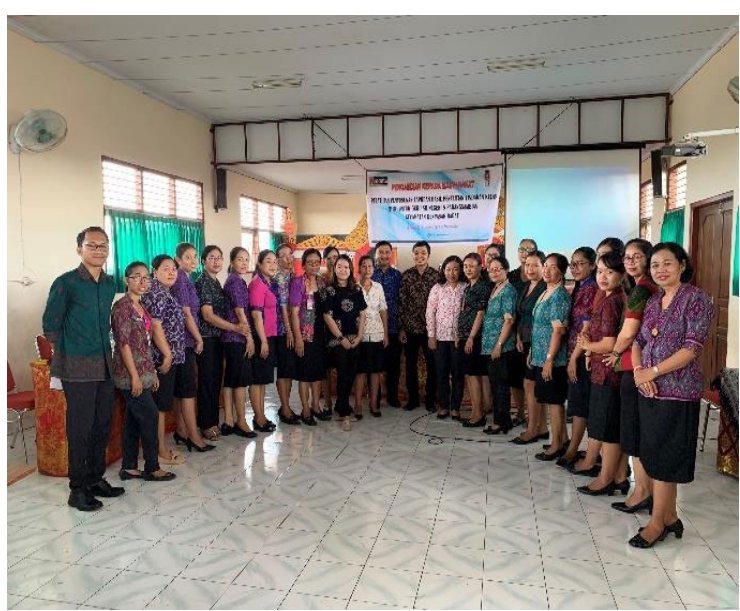

Gambar 7. Peserta pelatihan

\section{Hasil Pelaksanaan Kegiatan PKM}

Untuk mengukur keberhasilan kegiatan PKM yang telah dilakukan, maka dibuatlah angket untuk menguji kemampuan peserta sebelum dan sesudah pelatihan dilaksanakan, atau disebut juga pre-test dan post-test. Peserta diberikan soal yang sama untuk penyusuna laporan PTK. Selama kegiatan berlangsung, fasilitator mencatat kemampuan peserta dalam instrumen penilaian. Baik pretest ataupun post-test, peserta diberikan soal yang sama dan digunakan instrumen penilaian yang sama.

Pada instrumen penelitian terdapat beberapa komponen yang dinilai yaitu pemahaman terhadap penyusunan laporan PTK, terdiri dari: pemahaman terkait prosedur pelaksanaan Penelitian Tindakan Kelas (PTK), pemahaman dan kemampuan dalam menyusun bagian awal laporan hasil PTK, bagian isi laporan hasil PTK, dan bagian akhir PTK. Berikut merupakan instrumen penilaian yang digunakan saat melakukan pre-test dan post-test. 
INSTRUMEN PENILALAN PRE-TEST PELATIHAN PENYUSUNAN LAPORAN HASIL PENELITLAN TINDAKAN KELAS (PTK) UNTUK GURU SD NEGERI 5 PADANGSAMBIAN

NAMA GURU:

\begin{tabular}{|c|c|c|c|}
\hline No & \multirow{2}{*}{ KOMPONEN } & \multicolumn{2}{|l|}{ NILAI } \\
\hline \multirow{2}{*}{\multicolumn{3}{|c|}{ Prosedur pelaksanaan Penelitian Tindakan Kelas (PTK) }} & 15 \\
\hline 1. & Perencanaan tindakan & & \\
\hline 2. & Pelaksanaan tindakan & & \\
\hline 3. & Pengamatan/observasi dan pengumpulan data & & \\
\hline 4. & Refleksi & & \\
\hline \multirow{2}{*}{\multicolumn{4}{|c|}{ Bagian awal laporan hasil Penelitian Tindakan Kelas (PTK) }} \\
\hline 5. & Halaman Judul & & \\
\hline 6. & Halaman pengesahan disertai tanggal pengesahan & & \\
\hline 7. & Abstrak & & \\
\hline 8. & Kata pengantar disertai tanggal penyusunan & & \\
\hline 9. & Daftar Isi & & \\
\hline 10. & Daftar tabel/ lampiran & & \\
\hline \multicolumn{4}{|c|}{ Bagian Isi laporan hasil Penclitian Tindakan Kelas (PTK) } \\
\hline \multicolumn{4}{|c|}{ Bab I Pendahuluan } \\
\hline 11. & Latar Belakang Masalah & & \\
\hline 12. & Rumusan masalah & & \\
\hline 13. & Tujuan Penelitian & & \\
\hline 14. & Manfaat Penelitian & & \\
\hline \multicolumn{4}{|c|}{ Bab II Kajian Teori dan Pustaka } \\
\hline 15. & Kajian Teori tentang Variabel Masalah & & \\
\hline 16. & $\begin{array}{l}\text { Kajian teori variable Tindakan, serta Hasil Penelitian yang } \\
\text { Relevan }\end{array}$ & & \\
\hline 17. & Kerangka Berfikir & & \\
\hline \multicolumn{4}{|c|}{ Bab III Metode Penelitian } \\
\hline 18. & Subjek Penelitian & & \\
\hline 19. & Prosedur/Siklus Penelitian & & \\
\hline 20. & Teknik Pengumpulan Data & & \\
\hline 21. & Teknik Analisis Data & & \\
\hline \multicolumn{4}{|c|}{ Bab IV Hasil dan Pembahasan } \\
\hline 22. & Diskripsi Subjek penelitian & & \\
\hline 23. & Sajian Hasil Penelitian & & \\
\hline 24. & Pembahasan & & \\
\hline \multicolumn{4}{|c|}{ Bab V Simpulan dan Saran } \\
\hline 25. & Simpulan & & \\
\hline 26. & Saran & & \\
\hline \multicolumn{4}{|c|}{ Bagian akhir Penelitian Tindakan Kelas (PTK) } \\
\hline 27. & Daftar Pustaka & & \\
\hline 28. & Lampiran & & \\
\hline
\end{tabular}

Keterangan Nilai:

Pemahaman dan kemampuan dalam penyusunan tiap-tiap komponen

$1=$ tidak baik

$2=$ kurang baik

$3=$ cukup baik

$4=$ baik

$5=$ sangat baik

Gambar 8. Instrumen penelitian Pre-Test
INSTRU MEN PENILALA POST-TEST PELATIHAN PENYUSUNAN LAPORA TSTR padangsambian

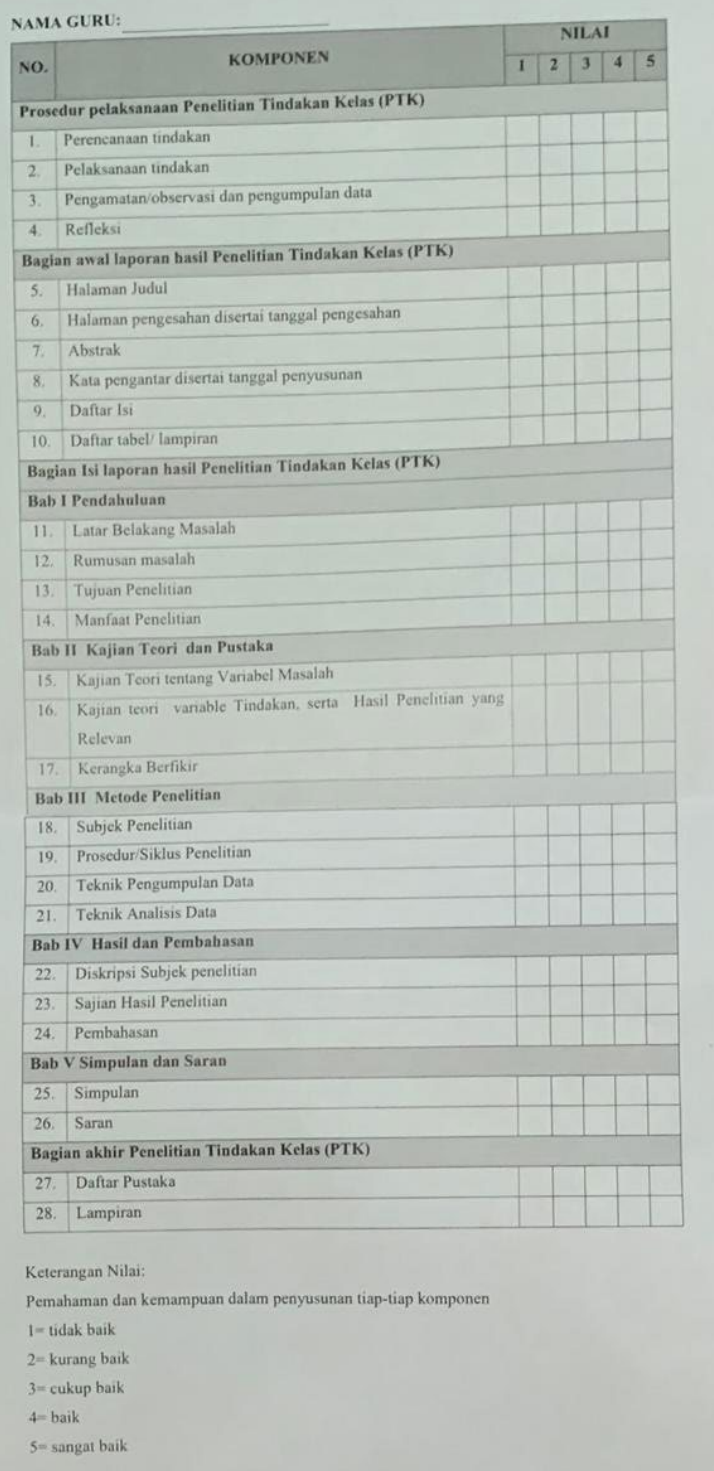

Gambar 9. Instrumen Penilaian Post-Test

Gambar 8 dan Gambar 9 merupakan instrumen penilaian yang digunakan untuk mengukur tingkat keberhasilan dari kegiatan PKM yang telah dilakukan. Komponen penilaian antara pre-test dan post-test yang digunakan adalah sama. Hal ini dilakukan untuk mengukur tingkat pemahaman peserta pelatihan sebelum dan sesudah mengikuti pelatihan.

Dari hasil penilaian yang telah dilakukan, diperoleh tingkat pemahaman peserta terhadap materi pelatihan yang diberikan berdasarkan penilaian pre-test dan post-test sebagai berikut: 
Tabel 2. Hasil Penilaian Pre-Test

\begin{tabular}{|c|c|c|c|c|c|c|}
\hline \multirow{2}{*}{ NO. } & \multirow{2}{*}{ KOMPONEN } & \multicolumn{5}{|c|}{ NILAI } \\
\hline & & 1 & 2 & 3 & 4 & 5 \\
\hline \multicolumn{7}{|c|}{ Prosedur PTK } \\
\hline 1 & Perencanaan tindakan & & 18 & 5 & 7 & \\
\hline 2 & Pelaksanaan tindakan & & 17 & 7 & 6 & \\
\hline 3 & \multicolumn{2}{|l|}{$\begin{array}{l}\text { Pengamatan/observasi } \\
\text { dan pengumpulan data }\end{array}$} & 16 & 7 & 7 & \\
\hline 4 & Refleksi & & 17 & 8 & 5 & \\
\hline \multicolumn{7}{|l|}{$\mathrm{A}$} \\
\hline 5 & Halaman Judul & & & 5 & 23 & 2 \\
\hline 6 & \multicolumn{2}{|l|}{$\begin{array}{lr}\begin{array}{l}\text { Halaman } \\
\text { disertai }\end{array} & \text { pengesahan } \\
\text { pengesahan } & \text { tanggal } \\
\end{array}$} & & 3 & 27 & \\
\hline 7 & \multicolumn{2}{|l|}{ Abstrak } & 18 & 7 & 5 & \\
\hline 8 & \multicolumn{2}{|l|}{$\begin{array}{l}\text { Kata pengantar disertai } \\
\text { tanggal penyusunan }\end{array}$} & 14 & 12 & 4 & \\
\hline 9 & \multicolumn{2}{|l|}{ Daftar Isi } & & 4 & 24 & 2 \\
\hline 10 & \multicolumn{2}{|l|}{ Daftar tabel/ lampiran } & & 5 & 23 & 2 \\
\hline \multicolumn{7}{|l|}{ B1 } \\
\hline 11 & $\begin{array}{ll}\text { Latar } & \text { Belak } \\
\text { Masalah } & \\
\end{array}$ & & 17 & 7 & 6 & \\
\hline 12 & \multicolumn{2}{|l|}{ Rumusan masalah } & 16 & 9 & 5 & \\
\hline 13 & \multicolumn{2}{|l|}{ Tujuan Penelitian } & 16 & 8 & 6 & \\
\hline 14 & \multicolumn{2}{|l|}{ Manfaat Penelitian } & 15 & 9 & 6 & \\
\hline \multicolumn{7}{|l|}{ B2 } \\
\hline 15 & \multicolumn{2}{|l|}{$\begin{array}{l}\text { Kajian Teori tentang } \\
\text { Variabel Masalah }\end{array}$} & 17 & 6 & 7 & \\
\hline 16 & \multicolumn{2}{|l|}{$\begin{array}{lr}\text { Kajian teori variable } \\
\text { Tindakan, serta } & \text { Hasil } \\
\text { Penelitian } & \text { yang } \\
\text { Relevan } & \\
\end{array}$} & 17 & 8 & 5 & \\
\hline 17 & \multicolumn{2}{|l|}{ Kerangka Berfikir } & 18 & 6 & 6 & \\
\hline \multicolumn{7}{|l|}{ B3 } \\
\hline 18 & \multicolumn{2}{|l|}{ Subjek Penelitian } & & 18 & 12 & \\
\hline 19 & \multicolumn{2}{|l|}{$\begin{array}{l}\text { Prosedur/Siklus } \\
\text { Penelitian }\end{array}$} & 15 & 8 & 7 & \\
\hline 20 & \multicolumn{2}{|l|}{$\begin{array}{l}\text { Teknik Pengumpulan } \\
\text { Data }\end{array}$} & 18 & 6 & 6 & \\
\hline 21 & \multicolumn{2}{|l|}{ Teknik Analisis Data } & 18 & 7 & 5 & \\
\hline B4 & & & & & & \\
\hline 22 & $\begin{array}{l}\text { Diskripsi Subjek } \\
\text { penelitian }\end{array}$ & 9 & 11 & 10 & & \\
\hline 23 & $\begin{array}{ll}\text { Sajian } & \text { Hasil } \\
\text { Penelitian } & \end{array}$ & 17 & 7 & 6 & & \\
\hline 24 & Pembahasan & 18 & 7 & 5 & & \\
\hline B5 & & & & & & \\
\hline 25 & Simpulan & 17 & 6 & 7 & & \\
\hline
\end{tabular}

\begin{tabular}{clccc}
\hline 26 & Saran & 16 & 6 & 8 \\
\hline $\mathrm{C}$ & & & & \\
\hline 27 & Daftar Pustaka & 18 & 7 & 5 \\
\hline 28 & Lampiran & 17 & 6 & 7 \\
\hline & TOTAL & 379 & 205 & 250 \\
\hline
\end{tabular}

Tabel 3. Hasil Penilaian Post-Test

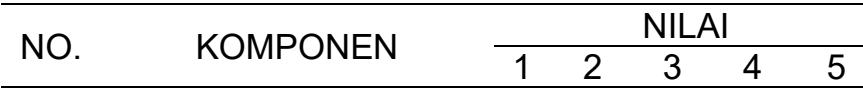
Prosedur PTK

Perencanaan tindakan Pelaksanaan tindakan Pengamatan/observasi dan pengumpulan data

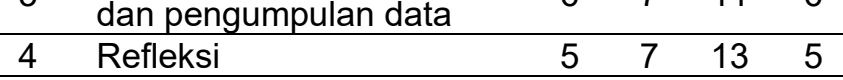

A

\begin{tabular}{lllll}
5 & Halaman Judul & 1 & 11 & 18 \\
\hline
\end{tabular}

Halaman pengesahan

$\begin{array}{llllll}6 & \text { disertai } & \text { tanggal } & 1 & 18 & 11\end{array}$ pengesahan

\begin{tabular}{clcccc}
7 & Abstrak & 6 & 7 & 9 & 8 \\
\hline 8 & $\begin{array}{l}\text { Kata pengantar disertai } \\
\text { tanggal penyusunan }\end{array}$ & 2 & 12 & 9 & 7 \\
\hline 9 & Daftar Isi & 2 & 11 & 17 \\
\hline 10 & Daftar tabel/ lampiran & 2 & 11 & 17 \\
\hline
\end{tabular}

B1

\begin{tabular}{llllll}
\hline 11 & $\begin{array}{l}\text { Latar Belakang } \\
\text { Masalah }\end{array}$ & 3 & 7 & 10 & 10 \\
\hline 12 & Rumusan masalah & 2 & 6 & 6 & 16 \\
\hline 13 & Tujuan Penelitian & 2 & 3 & 9 & 16 \\
\hline 14 & Manfaat Penelitian & 2 & 5 & 6 & 17 \\
\hline B2 & Kajian Teori tentang & 4 & 5 & 11 & 10 \\
15 & $\begin{array}{l}\text { Variabel Masalah } \\
\text { Varian }\end{array}$ & & & &
\end{tabular}

Kajian teori variable

16 Tindakan, serta Hasil

Penelitian yang

$\begin{array}{llll}3 & 3 & 10 & 14\end{array}$

Relevan

\begin{tabular}{clcccc}
\hline 17 & Kerangka Berfikir & 4 & 5 & 9 & 12 \\
\hline B3 & & & 2 & 13 & 15 \\
\hline 18 & Subjek Penelitian & 2 & 6 & 9 & 13 \\
\hline 19 & $\begin{array}{l}\text { Prosedur/Siklus } \\
\text { Penelitian }\end{array}$ & 3 & 7 & 8 & 12 \\
\hline 20 & $\begin{array}{l}\text { Teknik Pengumpulan } \\
\text { Data }\end{array}$ & 3 & 4 & 11 & 12 \\
\hline 21 & Teknik Analisis Data & & & & \\
\hline B4 & & 2 & 7 & 6 & 15 \\
\hline 22 & $\begin{array}{l}\text { Diskripsi Subjek } \\
\text { penelitian }\end{array}$ & 3 & 5 & 8 & 14 \\
\hline 23 & Sajian Hasil Penelitian & 3 & 6 & 7 & 14 \\
\hline 24 & Pembahasan & & & & \\
\hline B5 & & 2 & 8 & 4 & 16 \\
\hline 25 & Simpulan & 2 & 6 & 7 & 15 \\
\hline 26 & Saran & & & & \\
\hline C & & 1 & 8 & 13 \\
\hline 27 & Daftar Pustaka & & & &
\end{tabular}




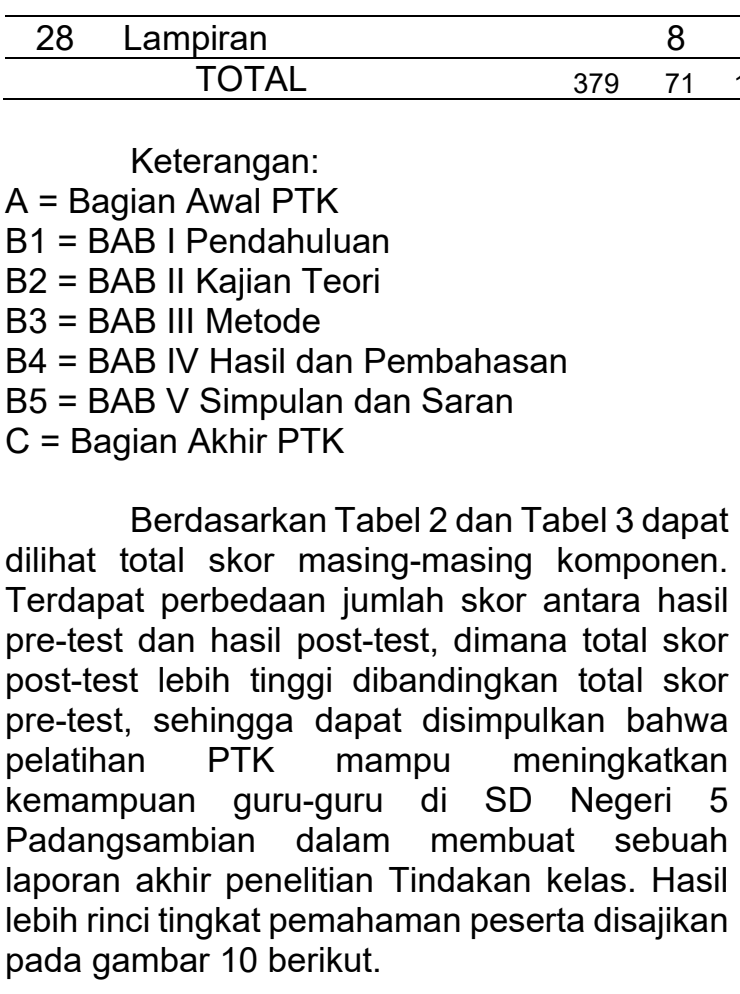

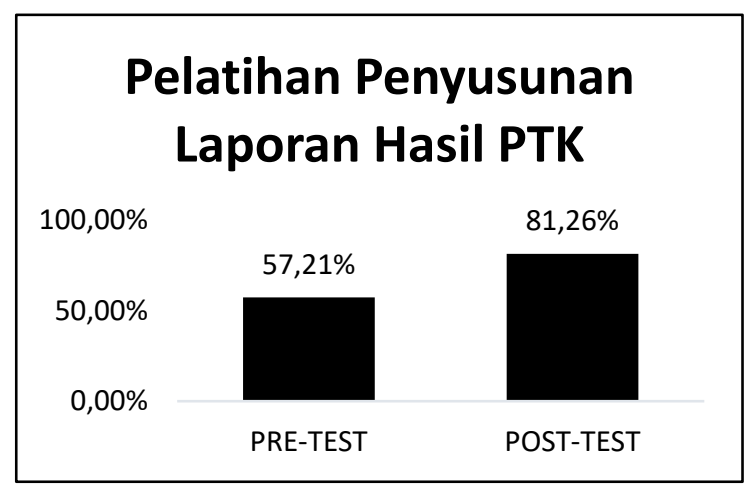

Gambar 10. Tingkat Pemahaman Peserta

Gambar 10 menunjukkan tingkat pemahaman peserta terhadap materi pelatihan yang diberikan. Hasil penilaian menunjukkan bahwa terjadi peningkatan pemahaman peserta sebelum dan sesudah mengikuti pelatihan. Sebelum mengikuti pelatihan penyusunan laporan PTK pemahaman peserta terhadap materi adalah $57,21 \%$, sedangkan setelah mengikuti pelatihan pemahaman peserta meningkat menjadi $81,26 \%$. Ini menunjukkan bahwa pelatihan yang telah dilakukan dalam kegiatan PKM di SD Negeri 5 Padangsambian, mampu meningkatkan pemahaman peserta terhadap materi penyusunan laporan PTK.

\section{SIMPULAN DAN SARAN}

Dari kegiatan pengabdian masyarakat yang dilakukan, dapat ditarik kesimpulan bahwa pelatihan penyusunan laporan PTK kepada guru-guru SD Negeri 5 Padangsambian 16yang telah dilakukan, mampu meningkatkan 26kemampuan guru-guru dalam penyusunan Taporan PTK sebesar 81,26\%

Adapun saran yang dapat diberikan adalah perlu dilakukan pelatihan mengenai penyusunan laporan PTK secara berkala untuk melakukan monitoring dan evaluasi terhadap kemampuan guru-guru.

\section{DAFTAR RUJUKAN}

Arikunto, S. (2006). Penelitian Tindakan Kelas. Jakarta: Bumi Aksara.

Basrowi \& Suwandi. (2008). Prosedur Penelitian Tindakan Kelas. Bogor: Ghalia Indonesia.

Furchan, H. (2004). Pengantar Penelitian dalam Pendidikan. Yogyakarta: Pustaka Pelajar.

Hartiny Sams, R. (2010). Model Penelitian Tindakan Kelas. Yogyakarta: Teras.

Saminato. (2010). Ayo Praktik PTK : Penelitian Tindakan Kelas. Semarang: Rasail Media Group.

Sanjaya, W. (2010). Penelitian Tindakan Kelas. Jakarta: Kencana.

Sudjana, N. (2001). Penilaian Proses Belajar Mengajar: Bandung: Tarsito

Sugiyono. (2009). Metode Penelitian Kuantitatif, Kualitatif, R\&D. Bandung: C.V. Alfabeta.

Wiriaatmadja, R. (2012). Metode Penelitian Tindakan Kelas. Bandung: PT Remaja Rosdakarya.

Yoni, A. (2010). Menyusun Penelitian Tindakan Kelas. Yogyakarta: Familia. 